Fisheries Science

May 2014, Volume 80 Issue 3 Pages 451-462

http://dx.doi.org/10.1007/s12562-014-0706-1

http://archimer.ifremer.fr/doc/00175/28659/

(C) The Japanese Society of Fisheries Science 2014

\title{
Quantification of eggs and sperm in the Black-lip pearl oyster Pinctada margaritifera using an enzyme-linked immunosorbent assay (ELISA)
}

\author{
Jeung Hee-Do ${ }^{1}$, Kang Do-Hyung ${ }^{2}$, Park Heung-Sik ${ }^{2}$, Le Moullac Gilles ${ }^{3}$, Choi Kwang-Sik ${ }^{1,{ }^{*}}$
}

1 Jeju Natl Univ, Sch Marine Biomed Sci, Cheju 690756, South Korea.

${ }^{2}$ Korea Inst Ocean Sci \& Technol, Global Bioresources Res Ctr, Ansan, South Korea.

${ }^{3}$ IFREMER, Ctr Pacifique, Lab Ecosyst Perlicole, Taravao, Fr Polynesia.

*Corresponding author : email address : skchoi@jejunu.ac.kr

\begin{abstract}
:
We have developed immunological probes to quantify eggs and sperm of the Black-lip pearl (BLP) oyster Pinctada margaritifera. The western blot assay revealed that the polyclonal antibodies developed in this study specifically recognized only egg and sperm proteins. These polyclonal antibodies also showed high sensitivities to the antigens, detecting $0.31-10 \mu \mathrm{g} / \mathrm{ml}$ of the egg or sperm proteins in an indirect enzyme-linked immunosorbent assay (ELISA). Accordingly, we used an indirect ELISA to quantify the eggs and sperm in BLP oysters collected in December 2009 from Weno Island in Micronesia and in May 2010 from Tahiti. The gonad somatic index (GSI), a ratio of gonad weight to somatic tissue weight, of the females collected from Weno Island ranged from 3.6 to $18.4 \%$, while the GSI of the females collected from Tahiti ranged from 5.6 to $12.6 \%$. Similarly, the GSI of the male BLP oysters from Weno Island ranged from 0.8 to $8.5 \%$, while the GSI of the males from Tahiti ranged from 4.8 to $7.5 \%$. These results lead to the conclusion that the immunological probes developed in this study can be successfully applied to quantify BLP oyster gonadal tissues and that these probes can be used in studies of BLP oyster reproductive ecology based on their sensitivity, rapidity, and affordability.
\end{abstract}

Keywords : Black-lip pearl oyster, ELISA, Pinctada margaritifera, Polyclonal antibody, Quantification of eggs and sperm 
The black lip pearl (BLP) oyster Pinctada margaritifera (Linnaeus, 1758) is widely distributed among the coral reefs of the tropical and subtropical region of the Indo-Pacific Ocean [1]. The black pearl production based on BLP oyster aquaculture has increased for the past two decades [2], and it plays a major economic role in island states in the South Pacific such as French Polynesia and Micronesia [3-4]. The BLP oyster aquaculture in French Polynesia and Micronesia mostly depends on naturally harvested spats as seeds, although the oyster spat supply from the wild is somewhat unstable and the intensive wild spat and brood stock collection has deteriorated the local pearl oyster populations [2, 4, 5]. Accordingly, the wild oyster fishing in the French Polynesia and the Micronesia has been suspended to conserve the natural pearl oyster populations [2, 4]. Alternatively, hatchery-based oyster seed production system has been attempted and currently, some portion of the seeds needed in the industry is supplied from the hatchery $[2,4,5]$.

For efficient management of marine bivalve hatchery operation, information of the reproductive physiology and ecology of the brood stock is essential, since crucial information necessary for the spat production can be obtained [3-4, 6-8]. Such reproductive biological information is also crucial in the development of a strategic management plan and development of a hatchery to produce the larvae for aquaculture or for enhancement of the wild population [9-10]. In particular, quantitative information of gamete production, such as the number of eggs or the weight is essential for the hatchery operation [11]. Several studies have reported that estimating reproductive effort of marine bivalve (i.e., the quantity of eggs or sperm) is difficult since most marine bivalves except scallops do not exhibit a discrete gonad and the gonads cannot be easily separated from the body [6, 12-14].

Immunological techniques have been widely used in reproductive biology of marine fishes and invertebrates since the techniques are highly sensitive and rapid [15-20]. In particular, ELISA has been successfully applied in quantification of marine bivalve eggs or sperm [6, 12-14, 21-23]. Recently, Uddin et al. [8] combined conventional histology and the ELISA technique together in the evaluation of reproductive condition and quantification of the reproductive effort of female Manila clam Ruditapes philippinarum [8]. In their study, the gametogenic stage of the female Manila clam was first examined from histological preparation of a dorso-ventral section of body $(10-20 \%$ of the total body weight) and the quantity of the eggs were determined from the lyophilized and homogenized body tissue using ELISA. Similarly, Mondol et al. [24] determined reproductive effort of hatchery produced Pacific oysters using histology-ELISA combined technique.

We develop polyclonal antibodies specific to the egg and sperm protein of BLP oysters to characterize and quantify the gonadal proteins. Here, we first report on the development of the immune probes and its application in quantification of BLP oyster eggs and/or sperm using ELISA.

\section{Materials and methods}

\subsection{Isolation and purification of the eggs and sperm}

To harvest the ripe eggs and sperm to be served as antigens, 30 female and 10 male BLP oysters with shell height ( $\mathrm{SH}$, maximal length of a shell in the dorso-ventral axis) over 120 $\mathrm{mm}$ were collected from Weno Island in Chuuk State, Federated State of Micronesia, by SCUBA diving (Fig. 1). The females and males collected in April and December 2008 from 
Weno Island exhibited fully-grown eggs and sperms in the visceral mass. The visceral mass containing either ripe eggs or sperm was removed, placed on a petri dish, and gently pressed to release the eggs and sperm [12, 22]. The crude egg and sperm extracts were then serially sieved with 100 and $40 \mu \mathrm{m}$ mesh to eliminate the tissue debris. The eggs and sperm extracts were further purified using a low-speed centrifugation (190×g for $10 \mathrm{~min}$ ) and this step was repeated several times. The total number of eggs in the purified eggs was counted using a hemocytometer under a light microscope to determine the weight of a single egg. The purified eggs and sperm were freeze-dried and stored at $-75^{\circ} \mathrm{C}$.

\section{2. Proximate composition of the eggs and sperms}

The total carbohydrate level in the eggs was determined using the phenol-sulfuric acid extraction method of Taylor with dextrose anhydrous as the standard material [25]. Total protein concentration in the eggs and sperm was determined using Lowry's method after hydrolyzing the eggs and sperms in $0.1 \mathrm{M} \mathrm{NaOH}$ at $37^{\circ} \mathrm{C}$ for $2 \mathrm{~h} \mathrm{[26].} \mathrm{Bovine} \mathrm{serum} \mathrm{albumin}$ (BSA) was used as the protein standard. Total lipid level in the eggs was determined gravimetrically by extracting the lipids using a mixture of chloroform and methanol and weighed according to Bligh and Dyer [27].

\subsection{Development of BLP oyster egg-specific and sperm-specific antibodies}

The purified BLP oyster eggs and sperm were first homogenized in phosphate buffered saline (PBS, $0.15 \mathrm{M} \mathrm{NaCl}, 0.003 \mathrm{M} \mathrm{KCl}, 0.01 \mathrm{M}$ phosphate, $\mathrm{pH} 7.4$ ) using an ultrasonifier. Concentration of the egg and sperm protein in the homogenates was determined using BCA Protein Assay (Pierce, USA) and adjusted to $1 \mathrm{mg} / \mathrm{ml}$ with PBS. To develop the antibodies, immunization protocols of Park and Choi [6] and Kang et al. [13] were used. In brief, a New Zealand white rabbit was first injected subcutaneously with $500 \mu \mathrm{l}$ of the egg or sperm homogenate mixed with an equal volume of Freund's complete adjuvant. The rabbits received booster injection at the third week with $0.5 \mathrm{ml}$ of $500 \mu \mathrm{g} / \mathrm{ml}$ egg protein or sperm homogenate mixed with $0.5 \mathrm{ml}$ of Freund's incomplete adjuvant. After the third booster injection, $5-10 \mathrm{ml}$ blood was withdrawn from the ear vein and specificity and the sensitivity of the antisera were tested using indirect ELISA and the Western immune blotting assay. After two months of immunization, $10-30 \mathrm{ml}$ of blood was withdrawn from the rabbits.

In indirect ELISA, both rabbit anti-BLP oyster egg protein and the anti-sperm protein antisera exhibited a weak but recognizable immuno-reaction to the non-gonadal somatic tissue proteins. Accordingly, the immunoadsorbent $[22,28]$ was prepared to remove the nonspecific antibodies in the antisera by polymerizing protein extracts of the somatic tissues including the mantle, gill and adductor muscle of BLP oysters. The antisera developed in this study were reacted with the immunoadsorbent for one $\mathrm{hr}$ at room temperature and centrifuged. After the reaction, the rabbit IgG in the antiserum was precipitated and harvested using saturated ammonium sulfate. The rabbit anti-BLP oyster egg protein IgG and anti-BLP oyster sperm protein IgG did not demonstrate cross-reaction to the somatic proteins in the indirect ELISA, indicating that the antibodies are only specific to the eggs or sperm proteins.

\subsection{SDS-PAGE and Western blotting}

To test specificity of the antibodies developed in this study, proteins of the BLP oyster eggs, sperms and other somatic tissues including mantle gill and digestive gland ( $2 \mu \mathrm{g}$ each) were 
extracted and electrophorized using $10 \%$ sodium dodecylsulfate polyacrylamide gel (SDSPAGE) with a known molecular marker (Precision Plus Protein Standards, Bio-Rad, USA) [29]. For the Western blotting assay, the protein bands separated by the electrophoresis were transferred onto a polyvinylidene difluoride (PVDF) membrane (PIERCE, USA) and blocked with $5 \%$ skim milk in TBS-T (Tris-buffered saline containing $0.05 \%$ Tween 20 ). After blocking, the rabbit anti-BLP oyster egg protein IgG or anti-BLP oyster sperm protein IgG $(3.0 \mu \mathrm{g} / \mathrm{ml})$ was applied to the membrane and incubated overnight at $4^{\circ} \mathrm{C}$. After incubation, the membrane was washed and reacted with goat anti-rabbit lgG horseradish peroxidase $(1.0 \mu \mathrm{g} / \mathrm{ml}$ in TBS-T, KOMA, Korea) as a secondary antibody for $1 \mathrm{hr}$ at room temperature. Finally, the membrane was reacted with the enhanced chemiluminescence $(E C L)$ reagents (PIERCE, USA) to visualize the antigen-antibody complex in gel documentation system (Chemi-Smart 2000, Vilber Lourmat, France). Images were captured using Chemi-capt (Vilber Lourmat, France) software and saved.

\subsection{Indirect enzyme linked immunosorbent assay (ELISA)}

For indirect ELISA, we followed the protocols of Park and Choi [6] and Kang et al. [13]. In brief, $100 \mu \mathrm{l}$ homogenate of the BLP oyster eggs and/or sperm $(20 \mu \mathrm{g} / \mathrm{ml})$ were serially diluted onto a polystyrene 96-well micro plate (GREINER, Switzerland) as positive controls, while PBS solution and different types of the somatic tissue homogenates were included in the plate as negative controls. In ELISA, the rabbit anti-BLP oyster egg protein IgG (2.1 $\mu \mathrm{g} / \mathrm{ml})$ or the rabbit anti-BLP oyster sperm protein $\mathrm{lgG}(3.0 \mu \mathrm{g} / \mathrm{ml})$ was served as the primary antibody along with $1 \mu \mathrm{g} / \mathrm{ml}$ of goat anti-rabbit lgG alkaline phosphatase-conjugated (SIGMA, USA) as the secondary antibody and the $\rho$-nitrophenylphosphate ( $\rho$-NPP, SIGMA, USA) substrate as the coloring reagent. Finally, the optical density of the colored antigen-antibody products in the plate was read at $405 \mathrm{~nm}$ wave length.

\section{6. mmunohistochemistry}

Immunohistochemical staining was carried out to visualize and localize the BLP oyster egg protein in the gonad. For the staining, a histological section of ripe female BLP oyster containing the fully-grown eggs was sliced to $6 \mu \mathrm{m}$, mounted on a glass slide, deparaffinazed and rehydrated. The tissue slide was immersed in $10 \mathrm{mM}$ sodium citrate buffer $\left(\mathrm{pH} \mathrm{6)}\right.$ and treated with $3 \% \mathrm{H}_{2} \mathrm{O}_{2}$ solution to quench the endogenous peroxide from the tissue section. The tissue section was incubated in 5\% BSA dissolved in PBS-T (Triton-X $100)$ as a blocking buffer. After blocking, the tissues were submerged in the rabbit anti-BLP oyster egg protein IgG $(63.0 \mu \mathrm{g} / \mathrm{ml})$ solution and incubated for overnight at $4^{\circ} \mathrm{C}$. For the negative control, the pre-immune rabbit serum (1:100 v/v dilution) was served as the primary antibody. After washing, $10 \mu \mathrm{g} / \mathrm{ml}$ of the fluorescein isothiocyanate-conjugated (FITC) goat anti-rabbit IgG (SIGMA, USA) was applied on the slide and incubated for one hour. The slide was then washed several times with PBS-T and the antibody-antigen reaction in the slide was then examined under a fluorescence microscope (Olympus, Japan).

\subsection{Quantification of the eggs and sperm using indirect ELISA}

In December 2009, 136 BLP oysters were collected from a lagoon at Weno Island and in May 2010, 20 BLP oysters were collected from IFREMER hatchery in Tahiti, French Polynesia. To evaluate the reproductive maturity of BLP oysters, a $2 \mathrm{~mm}$ thick section was made longitudinally in the middle of the body and then fixed in Davidson's fixative. The fixed tissues were subjected to histology and the reproductive condition was graded as 
developing, ripe, spawning/partially spawned and spent $[4,30]$. The remaining tissue was lyophilized for quantification of the eggs or sperm in the tissues. Table 1 summarizes the mean size of the oysters analyzed using the immune probes developed in this study.

To measure the amount of BLP oyster egg in an individual oyster, an indirect ELISA was applied according to Park and Choi [6], Uddin et al. [8] and Kang et al. [13]. In brief, $100 \mathrm{mg}$ of the lyophilized and grounded female oyster tissue was further homogenized in PBS-T using an ultrasonifier and diluted up to 1,000 folds. In indirect ELISA, known quantity of the purified BLP oyster egg homogenate $(0.08-5.0 \mu \mathrm{g} / \mathrm{ml})$ was included as the standard. Also, standards and BLP oyster homogenates were tested triplicates. The quantity of egg protein in the oyster tissue was then determined from a standard regression curve constructed using optical density of the purified BLP oyster egg standards included in each microplate. The amount of egg in each oyster was then determined by multiplying the quantity of the egg protein estimated by ELISA by 2.2, the ratio of the egg protein (45\%) to the total egg weight determined in this study. Finally, the quantity of egg in an oyster was expressed as the gonad somatic index (GSI), the weight percentage of the eggs in the total oyster tissue (\%). Potential fecundity was also determined based on the ELISA results, by dividing the total weight of the eggs determined from the ELISA by the weight of ripe individual egg determined in this study, as $14.3 \mathrm{ng}$.

The GSI of male BLP oysters was also determined using indirect ELISA with the rabbit antiBLP oyster sperm protein IgG as the primary antibody. As a positive control, as well as the standard, a known amount of purified BLP oyster sperm $(0.08-5.0 \mu \mathrm{g})$ was included on each microplate. For the quantification, $100 \mathrm{mg}$ of the male oyster tissue homogenate was further homogenized in PBS-T and diluted up to 300 fold. In indirect ELISA, the standards and BLP oyster homogenates were added into the microplate in triplicate. The quantity of sperm protein in an individual male BLP oyster was then determined from a standard regression curve which plotted the optical density of the standard to the mass of the purified sperm protein. The quantity of sperm was then estimated by multiplying the amount of the sperm protein measured by ELISA by 6.7 , the ratio of sperm protein $(15 \%)$ to the total sperm weight determined in this study. Finally, the quantity of sperm in an individual male BLP oyster was expressed as the GSI, a ratio of the sperm weight to the total tissue weight.

\section{Results}

\subsection{Biochemical composition of egg and sperm}

Ripe BLP oyster egg and sperm were successfully isolated and purified using the different sizes of meshes and centrifugation. Proximate biochemical analysis (mean with standard deviation) indicated that the purified egg was composed of $45.5 \pm 7.0 \%$ protein, $21.5 \pm 2.4 \%$ lipid, and $5.8 \pm 1.3 \%$ carbohydrate in $\mathrm{mg}$ dry weight. In contrast, the total protein in the purified sperm was accounted for $7.5 \pm 4.4 \%$. The dry weight of a single mature BLP oyster egg was determined to be $14.3 \mathrm{ng}$. 


\subsection{Western blotting assay}

SDS-PAGE and the subsequent Western blotting assay (Fig. 2) indicated that the BLP oyster egg protein was composed of peptides of various molecular sizes including 23, 39, 42, 49, 73, 83, 100, 154, $283 \mathrm{kDa}$ and a fragment size bigger than $300 \mathrm{kDa}$, (Fig. 2b). As shown in Fig. 2a, the rabbi anti BLP oyster egg protein $\operatorname{lgG}$ showed a strong binding to the BLP oyster egg proteins (Fig. 2a, lane 1) but it also showed weak but recognizable binding to the protein extract of other tissues such as mantle, gill, digestive gland and sperm (Fig. 2a, lanes 2, 3, and 4). The cross-reacting antibodies included in the original antiserum were removed by treating the antiserum with immunoadsorbent prepared by polymerizing the somatic tissue proteins and the Western blotting assay was carried out again. As shown in Fig. $2 b$, the immunoadsorbent treated rabbit anti-BLP oyster egg IgG showed strong binding to the numerous egg peptides ranged from 23 to $283 \mathrm{kDa}$ and a fragment bigger than 300 $\mathrm{kDa}$, but did not demonstrate any immune reaction to the somatic proteins, indicating that the antibody is specific only to the egg peptides.

Figure 3 shows an indirect ELISA titration curve used in the quantification of the reproductive effort of female BLP oysters. As was demonstrated in the Western blotting assay, the original rabbit anti-BLP oyster egg protein IgG showed weak, recognizable cross-reactivity over the somatic tissue protein (Fig. 3a). After removing the cross-reacting antibodies in the antiserum by the immunoadsorbent, the rabbit anti-BLP oyster egg protein IgG no longer exhibited an immune reaction to the somatic tissue proteins, indicating that the antibody is specific only to the egg protein (Fig. 3b). In the indirect ELISA, the rabbit anti-BLP oyster egg protein $\mathrm{lgG}$ detected as low as $40 \mathrm{ng} / \mathrm{ml}$ of the egg protein (Fig. 3b). The antibody-antigen reaction of the rabbit anti-BLP oyster egg lgG was also visualized using the immunohistochemical staining. As Fig. 4 showed, the rabbit anti-BLP oyster egg protein IgG bound mainly to the yolk granules in the mature eggs, indicating that the rabbit antibody was raised from the yolk granules (Fig. 4b).

\subsection{Development of rabbit anti-BLP oyster sperm protein antibody}

The rabbit anti-BLP oyster sperm protein antiserum developed in this study showed a strong immune reaction to the sperm protein (Fig. 5a, lane 1), although it also showed immune reactions to the negative controls including the egg protein and other somatic proteins (Fig. $5 a$, lanes 2 to 6 ). As was applied in the development of the egg specific antibody, the crossreacting antibodies were removed using the immunoadsorbent prepared by polymerizing the somatic protein extract. After removing the cross-reacting antibodies in the antiserum, the rabbit anti-BLP oyster sperm protein IgG specifically reacted only to the sperm protein (Fig. $5 \mathrm{~b}$, lane 1 ), and the antibody did not show immune reactions to the somatic proteins (Fig. $5 \mathrm{~b}$, lanes 2 to 6). As Fig. 5b demonstrated, the rabbit anti-BLP oyster sperm protein IgG showed a strong immune reaction to the sperm protein peptide of $27.5 \mathrm{kDa}$.

The specificity of the rabbit anti-BLP oyster sperm protein IgG was also tested using indirect ELISA. As Fig. 6a showed, the original rabbit antibody raised from the sperm protein did demonstrate immune reaction to the sperm protein as well as to the somatic tissue proteins. However, the cross-reacting antibodies were removed by mixing the original antiserum with the immunoadsorbent and the specificity of the antibody was tested again. As Fig. 6b demonstrated, the rabbit anti-BLP oyster sperm protein lgG treated with the immunoadsorbent showed a strong immune-reaction to the BLP oyster sperm protein but it showed only negligible reaction to the somatic tissues. In indirect ELISA, the rabbit anti-BLP oyster sperm protein $\mathrm{lgG}$ detected 0.31 to $10.00 \mu \mathrm{g} / \mathrm{ml}$ of the sperm protein (Fig. 6a). 


\subsection{Quantification of the eggs and sperm using indirect-ELISA}

Histology revealed that BLP oysters collected from Weno Island in December, 2009 consisted of 36 females and 100 males. Accordingly, the reproductive effort of the 36 females was estimated using the immune probe developed in this study. Histology revealed that reproductive stages of the females collected from Weno Island consisted of developing, ripe, spawning, and spent, while the females from Tahiti were mostly in the ripe stage. The reproductive effort of the females determined by indirect ELISA was expressed as the gonad-somatic index (GSI), a ratio of the egg mass to the total tissue weight.

The mean GSI of the females collected from Weno Island ranged from $3.6 \pm 2.6 \%$ in spent stage (mean \pm standard deviation) to $18.4 \pm 5.7 \%$ in ripe stage. Of the 20 BLP oysters collected from Tahiti, histology indicated that there were 9 females in developing, ripe, and spawning stages. The mean GSI of the females from Tahiti varied from $5.6 \%$ (developing stage, $\mathrm{N}=1$ ) to $12.6 \pm 3.3 \%$ (ripe stage, Fig. 7).

The potential fecundity of the ripe BLP oysters was also estimated by dividing the total egg weight with the single egg dry weight $(14.3 \mathrm{ng})$ determined in this study. Potential fecundity of the ripe females from Weno Island varied from 41.1 to 191.4 million eggs with a mean of 93.9 million. Similarly, the potential fecundity of BLP oysters from Tahiti ranged from 44.7 to 120.9 million eggs with a mean of 73.7 million. A strong positive correlation was observed between size of the females and the fecundity $\left(r^{2}=0.539, p<0.05\right.$ for Weno and $r^{2}=0.402$, $p<0.05$ for Tahiti), suggesting that the larger females produce more eggs than the small oysters (Fig. 8).

Figure 9 shows the reproductive effort of the males in different reproductive stages. Histology indicated that 100 and 11 male BLP oysters from Weno Island and Tahiti respectively were used in the assay. The mean GSI of the male BLP oysters collected from Weno Island ranged from $0.8 \pm 1.0 \%$ (spent stage) to $8.5 \pm 3.8 \%$ (ripe stage), while the GSI of the males from Tahiti varied from $4.8 \pm 2.7 \%$ (developing stage) to $7.5 \%$ (ripe stage, $N=1$, Fig. 9).

\section{Discussion}

\subsection{Biochemical properties of $P$. margaritifera egg and sperm}

In the present study, we first determined the biochemical composition of BLP oyster eggs which is essential information for the hatchery development of BLP oyster [31-33]. Table 2 summarizes dry weight of egg and percentage composition of protein, carbohydrate, and lipids of various marine bivalves. Like other marine bivalve eggs, protein is the major constituent of BLP oyster eggs, comprising $45.5 \pm 7.0 \%$ of the dry weight. Dry weight of a fully-grown single egg of BLP oyster estimated in this study was $14.3 \mathrm{ng}$ and the weight is also comparable to other oysters such as Crassostrea virginica [32] and $C$. gigas [13]. In contrast, the BLP oyster eggs have comparatively higher lipid content than those of clams including Merceneria mercenaria [32] and Saxidomus purpuratus [22], although the lipid level in the BLP oyster egg is similar to the level of other oyster species.

BLP oyster sperm was also successfully isolated from fully grown males and purified by serial sieving and washing with centrifugation. Choi et al. [12] also purified the American oyster C. virginica sperm using density gradient fluid (PERCOL, Sigma) with low speed centrifugation. In this study, the total protein in the BLP oyster sperm accounted for $3-15 \%$ of 
the sperm dry weight, which is comparable to the level reported by Choi et al. [12] as $13 \%$ for $C$. virginica.

\subsection{Specificity and sensitivity of antibodies developed in this study}

Although the polyclonal antiserum developed from the BLP oyster eggs initially showed strong immunoreactivity to the oyster egg protein, the antiserum also exhibited a weak but recognizable non-specific reaction to the somatic tissue proteins extracted from the mantle and gills (Fig. 2a and Fig. 3a). The non-specific immunoreactivity of the rabbit antiserum could be originated from some proteins common to the egg and other somatic tissues. It is believed that the rabbit also produced antibody to these non-gonadal common proteins as well as to other egg-specific proteins since the antibody developed in this study is polyclonal. This non-specific immunoreactivity of polyclonal antibody developed from eggs or sperm of marine bivalves has been reported from a small numbers of studies. Choi et al. [12] first developed polyclonal antibodies from egg and sperm of the eastern oyster $C$. virginica, and the antisera exhibited weak immune responses to the somatic tissues including mantle and gills. Similarly, Osada et al. [34] observed such non-specific antigen-antibody reactions in the polyclonal antisera developed from egg proteins of the Yesso scallop Patinopecten yessoensis, and such cross-reaction was also confirmed in the development of polyclonal antibody to egg proteins of the Pacific oyster $C$. gigas $[13,15]$. However, the non-specific antibodies presented in the antiserum were successfully removed by the immunoadsorbent, prepared by acetone-drying [12], or polymerizing the somatic tissue proteins [6, 13, 21-22]. The SDS PAGE of the BLP oyster egg protein yielded numerous fragments and the egg peptides showed positive immune reaction to the rabbit anti-BLP oyster egg protein IgG developed in this study (Fig. 2b). It is believed that the large molecular weight fragments included in the BLP oyster egg protein are vitellin, which is the major constituent of marine bivalve eggs as well as other marine invertebrate animal egg [6, 13, 22, 34]. Several studies also have characterized marine bivalve egg proteins using SDS PAGE, including the Eastern and Pacific oyster $C$. virginica [32] and C. gigas [15], the Hard clam $M$. mercenaria [32] and S. purpuratus [21], the Yesso scallop $P$. yessoensis [34], and the Manila clam $R$. philippinarum [6]. These studies also confirmed that the egg protein is composed of several peptides with molecular weight ranging $17-330 \mathrm{kDa}$.

As shown in Fig. 5b, the rabbit anti-BLP oyster sperm protein was raised from a single low molecular mass peptide of $27.5 \mathrm{kDa}$. Unlike the oyster egg, the sperm contained less amount of protein, possibly presented in the flagellum [35]. In indirect ELISA, the rabbit antiBLP oyster sperm IgG detected as little as $0.31 \mu \mathrm{g} / \mathrm{ml}$ of the sperm protein (Fig. 6b). Indirect ELISA was also successfully applied in the quantification of the American oyster sperm protein, and Choi et al. [12] also developed polyclonal antibody against to the sperm protein of $C$. virginica. The rabbit anti- $C$. virginica sperm $\lg G$ was also sensitive enough to detect small quantity of the sperm protein presented in the mixture of the oyster somatic proteins, detecting $0.10-10.00 \mu \mathrm{g} / \mathrm{ml}$ of the sperm protein. Therefore, we could conclude that our rabbit anti-BLP oyster sperm protein IgG was successfully developed in this study, and it will be expected that the rabbit anti-BLP oyster sperm protein IgG usefully used in the reproductive biological studies of BLP oyster sperm.

\subsection{Reproductive effort of $\boldsymbol{P}$. margaritifera}

Various methods have been applied in the quantification of reproductive effort of pearl producing marine bivalves (Table 3). Based on histology, Cáceres-Puig et al. [36] measured the gonad volume fraction of the Winged pearl oyster Pteria sterna in Mexican waters. 
According to their study, $P$. sterna accumulated as much as $400 \%$ of the energy from early development to the ripe stage and $200 \%$ of the basal energy was lost after spawning. Hart and Friedman [37] estimated the fecundity of gold- or silver-lip pearl oyster Pinctada maxima in Western Australia by dissecting the gonad from formalin fixed visceral mass. According to the study, the ripe gonad occupied $18-29 \%$ of the visceral mass and the fecundity ranged from 19.7-29.5 million eggs. Alansari et al. [38] also determined fecundity of the Atlantic pearl oyster by counting the released eggs from spawning females. They estimated the fecundity of $P$. radiata as $0.95-1.7$ million eggs. A few studies have reported reproductive effort of the BLP oysters, either the GSI or the fecundity. In the French Polynesia, Pouvreau et al. [3] measured weights of the ripe female before and after the spawning. In their monitoring, the ripe females lost $4-11 \%$ of the tissue weight during the spawning, although the number of eggs released from the spawning event was unknown. Ehteshami et al. [39] also estimated fecundity of the BLP oysters in the Persian Gulf by counting the number of eggs released from spawning females. According to Ehteshami et al. [39], female $P$. margaritifera conditioned at a hatchery for 24 days yielded 2.5-20.0 million eggs during spawning. Regarding these, although many researchers tried to quantify the RE of pearl oyster species, but those methods described above have some disadvantages. It is that histological preparation and counting the gametes are demand time consuming and may often under- or overestimate the true RE $[6,13]$, because the pearl oysters in tropical regions are continuous spawning species and the spawning is always incomplete [3,7]. Alternatively immunological methods (i.e. ELISA) have been used to assess the RE of marine bivalves, because it could measure true quantity of egg mass in an individual oyster or clam, and rapid, highly sensitive enough to quantify small amount of egg protein in oysters $[6,8-10,12-$ 14, 22-24].

The present study determined GSI and fecundity of the female BLP oysters from Weno Island in Micronesia and Tahiti Island in French Polynesia, the two major BLP oyster culture areas in the Pacific ocean, using an indirect ELISA. In this study, the fecundity was estimated from the total biomass of egg determined by ELISA, by dividing the egg mass by the weight of a single mature egg determined in this study as $14.3 \mathrm{ng}$. Since the single egg weight may vary with its size in different gametogenic stages the fecundity estimation was limited to ripe females. In the present study, the reproductive stage of the female used in the quantification of the egg mass could be determined since a small portion of the body was histologically prepared and examined under a light microscope. Accordingly, this is the first attempt to define the stage-wise reproductive effort of the BLP oysters. Recently, Uddin et al. [8] and Mondol et al. [24] also determined GSI of the Manila clam Ruditapes philippinarum and the Pacific oyster Crassostrea gigas using histology-ELISA combined technique, and GSI of the clams and oysters in different reproductive conditions could be assessed. As Figure 7 shows, the GSI of the female BLP oysters in ripe stage (12.6-18.4\%) is 2-3 times higher than GSI of the females in the developing stage $(5.6-8.1 \%)$ or in partial spawning (7.6-8.0\%). Fecundity, as the number of eggs in ripe oysters determined in this study, also ranged 41.1-191.4 million with a mean of 93.9 million eggs in Weno Island and 44.7-120.9 million with a mean of 73.7 million eggs in Tahiti. The GSI of the BLP oysters estimated in this study (3.6-18.4\%) is comparatively higher than the GSI reported by Pouvreau et al. [3] as $4-11 \%$. The fecundity of the ripe females estimated in this study is also much higher than the fecundity reported by Ehteshami et al. [39] as 2.5-20.0 million eggs. The comparatively higher GSI and the fecundity of the females recorded in this study could be in part, explained by the different methods used in the quantification. As marine bivalves are induced to spawn by thermal or chemical shocks, responses of the individuals to the stimulation vary depending upon their reproductive/physiological conditions, and spawning is partial in most cases, meaning that not all the eggs in the follicles are released during spawning [40-43]. Accordingly, the fecundity estimated in the previous studies, by counting the number of released eggs would underestimate the fecundity since not all the eggs would be released during spawning. Similarly, GSI of the female estimated by weighing the tissue weight before 
and after the spawning would also underestimate the true quantity of the egg, if the oysters were not reproductively mature and ready for spawning. In contrast, the GSI of the ripe female oysters estimated in our study is considered to be "maximal", since all the eggs in an individual oyster is homogenized and assessed using ELISA.

In summary, the BLP oyster egg and sperm specific polyclonal antibodies were developed in this study to assess the quantity of eggs and sperm. In indirect ELISA, the polyclonal antibodies showed high specificities and sensitivities to the eggs or sperm proteins mixed in the somatic tissue proteins. The indirect ELISA technique developed in this study was rapid, sensitive and affordable in the quantification of reproductive effort, and the technique is expected to be applied widely in the reproductive biology of the BLP oyster.

\section{Acknowledgements}

This study was supported by International collaboration Study (PM55800) of the Korea Institute of Ocean Science and Technology (KIOST) grant funded by the Korea Government Ministry of Ocean and Fisheries. Authors also deeply appreciate financial support from KIOST (PE99161).

\section{References}

[1] Wada TK, Tëmkin I (2008) Taxonomy and Phylogeny. In: Southgate PC and Lucas JS (eds), The Pearl Oyster, Elsevier, Amsterdam, Nertherlands, pp 37-75

[2] Arnaud-Haond S, Vonau V, Bonhomme F, Boudry P, Prou J, Seaman T, Veyret M, Goyard E (2003) Spat collection of the pearl oyster (Pinctada margaritifera cumingii) in French Polynesia: an evaluation of the potential impact on genetic variability of wild and farmed populations after 20 years of commercial exploitation. Aquaculture 219: 181-192

[3] Pouvreau S, Gangnery A, Tiapari J, Lagarde F, Garnier M, Bodoy A (2000) Gametogenic cycle and reproductive effort of the tropical blacklip pearl oyster, Pinctada margaritifera (Bivalvia: Pteriidae), cultivated in Takapoto Atoll (French Polynesia). Aquat Living Res 13: 37-48

[4] Kang DH, Park HS, Yi SK, Choi KS (2005) Reproductive condition of the tropical blacklip pearl oyster, Pinctada margaritifera (Linnaeus 1758) from Chuuk Lagoon, Federated State of Micronesia during the summer months in 2003 (in Korean with English abstract). Ocean Polar Res 27: 351-358

[5] Ellis S, Haws M (1999) Producing pearls using the Black-lip pearl oyster (Pinctada margaritifera). Center for Tropical and Subtropical Aquaculture Publication, 141, Hawaii, pp 1-8

[6] Park KI, Choi KS (2004). Application of enzyme-linked immunosorbent assay for studying of reproduction in the Manila clam Ruditapes philippinarum (Mollusca: Bivalvia): I. Quantifying eggs. Aquaculture 241: 667-687

[7] Le Moullac G, Tiapari J, Teissier H, Martinez E, Cochard JC (2012) Growth and gonad development of the tropical black-lip pearl oyster, Pinctada margaritifera (L.), in the Gambier archipelago (French Polynesia). Aquacult Int 20: 305-315 
[8] Uddin MJ, Yang HS, Park KJ, Kang CK, Kang HS, Choi KS (2012). Annual reproductive cycle and reproductive efforts of the Manila clam Ruditapes philippinarum in Incheon Bay off the west coast of Korea using a histology-ELISA combined assay. Aquaculture 364365: 25-32

[9] Joaquim S, Matias D, Lopes B, Arnold WS, Gaspar MB (2008). The reproductive cycle of white clam Spisula solida (L.) (Mollusca: Bivalvia): Implications for aquaculture and wild stock management. Aquaculture 281: 43-48

[10] Limpanont Y, Yang HS, Park KI, Choi KS (2011) First report on the annual gametogenesis of Heteromacoma irus (Hanley, 1845) in a rocky intertidal area, northern Jeju Island, Korean. J Shellfish Res 30 (1): 39-46

[11] Gosling EM (2003) Bivalve Molluscs: Biology, Ecology and Culture. Fishing News Book, Oxford, UK

[12] Choi KS, Lewis DH, Powell EN, Ray SM (1993) Quantitative measurement of reproductive output in the American oysters, Crassostrea virginica, using and enzymelinked immunosorbent assay (ELISA). Aquacult Fish Manage 24: 375-398

[13] Kang SG, Choi KS, Bulgakov AA, Kim Y, Kim SY (2003) Enzyme-linked immuosorbent assay (ELISA) used in quantification of reproductive output in the pacific oyster, Crassostrea gigas, in Korea. J Exp Mar Biol Ecol 282: 1-21

[14] Long WC, Bromage E, Seitz RD, Kaattari S (2008). Quantifying fecundity in Macoma balthica using an enzyme-linked immunosorbent assay (ELISA). Aquat Biol 3: 187-193

[15] Suzuki T, Hara A, Yamaguchi K, Mori K (1992) Purification and immunolocalization of a vitellin-like protein from the Pacific oyster Crassostrea gigas. Mar Biol 113: 239-245

[16] Bon E, Barbe U, Rodriguez JN, Cuisset B, Pelissero C, Sumpter JP, Le Menn F (1997) Plasma vitellogenin levels during the annual reproductive cycle of the female rainbow trout (Oncorhynchus mykiss): Establishment and validation of an ELISA. Comp Biochem Physiol Part B 117: 75-84

[17] Fukada H, Hiramatsu N, Gen K, Hara A (1997). Development of an ELISA for Chum Salmon (Oncorhynchus keta) growth hormone. Comp Biochem Physiol Part B 117: 387392

[18] Chen L, Jiang H, Zhou Z, Li K, Li K, Deng GY, Liu Z (2004) Purification of vitellin from the ovary of Chinese mitten-handed crab (Eriocheir sinensis) and development of an antivitellin ELISA. Comp Biochem Physiol Part B 138: 305-311

[19] Roy RL, Morin Y, Courtenay SC, Robichaud P (2004) Purification of vitellogenin from smooth flounder (Pleuronectes putnami) and measurement in plasma by homologous ELISA. Comp Biochem Physiol Part B 139: 235-244

[20] Leung MYK, Ho WKK (2006). Production, characterization and applications of mouse anti-grass carp (Ctenopharyngodon idellus) growth hormone monoclonal antibodies. Comp Biochem Physiol Part B 143: 107-115

[21] Park KI, Choi JW, Choi KS (2003). Quantification of reproductive output of the butter clam, Saxidomus purpuratus (Sowerby, 1852) using enzyme-linked immunosorbent assay (ELISA). Ocean Polar Res 25: 249-256

[22] Park KI, Choi JW, Choi KS (2005) Development of a Saxidomus purpuratus (Mollusca: Bivalvia) egg-specific antibody for the quantification of eggs using an enzyme-linked immunosorbent assay. J Shellfish Res 24: 1079-1086

[23] Royer J, Sequineau C, Park KI, Pouvreau S, Choi KS, Costil K (2008). Gametogenetic cycle and reproductive effort assessed by two methods in 3 age classes of Pacific oyster, Crassostrea gigas, reared in Normandy. Aquaculture 277: 313-320

[24] Mondol MR, Kim CW, Kim BK, Kang CK, Choi KS (2012) Early growth and reproduction of hatchery-produced Pacific oyster Crassostrea gigas in Gamakman Bay off the southern coast of Korea. Fish Sci 78: 1285-1292

[25] Taylor KACC (1995) A modification of the phenol sulfuric acid method of total sugar determination. Appl Biochem Biotechnol 53: 207-214

[26] Lowry OH, Rosebrough NJ, Farr AL, Randall RJ (1951) Protein measurement with the Folin phenol reagent. J Biol Chem 10: 203-206 
[27] Bligh EG, Dyer WF (1959) A rapid method of total lipid extraction and purification. Can J Biochem Physiol 37: 911-917

[28] Fuchs S, Sela M (1979) Immunoadsorbents. In: Weir DM (ed), Handbook of Experimental Immunology, Immunochemistry, vol. 1. Blackwell Scientific Publications, Philadelphia, USA, pp 16.1-16.5

[29] Laemmli UK (1970) Cleavage of structural proteins during the assembly of the head of bacteriophage T4. Nature 277: 680-685

[30] Saucedo PE, Southgate PC (2008) Reproduction, Development and Growth. In: Southgate PC and Lucas JS (eds), The Pearl Oyster, Elsevier, Amsterdam, Nertherlands, pp 131-186

[31] Devauchelle N, Mingant C (1991) Review of the reproductive physiology of the scallop, Pecten maximus, applicable to intensive aquaculture. Aquat Living Res 4: 41-51

[32] Lee RF, Heffernan PB (1991) Lipids and proteins in eggs of eastern oysters (Crassostrea virginica (GNELIN, 1791)) and northern quahogs (Mercenaria mercenaria (Linnaeus, 1758)). J Shellfish Res 10: 203-206

[33] Massapina C, Joaquim S, Matias D, Devauchelle N (1999) Oocyte and embryo quality in Crassostrea gigas (Portuguese strain) during a spawning period in Algarve, South Portugal. Aquat Living Res 12 (5): 327-333

[34] Osada M, Unuma T, Mori K (1992) Purification and characterization of a yolk protein from the scallop ovary. Nippon Suisan Gakkaishi 58: 2283-2289

[35] Kingtong S, Kellner K, Bernay B, Goux D, Sourdaine P, Berthelin CH (2013) Proteomic identification of protein associated to mature spermatozoa in the Pacific oyster Crassostrea gigas. J Proteomics 82: 81-91

[36] Cáceres-Puig JI, Cáceres-Martínez C, Saucedo PE (2009) Annual reproductive effort of pacific winged pearl oyster Pteria sterna and its relation with the timing for planning pearl seeding operations. J Shellfish Res 28: 471-476

[37] Hart AM, Friedman KJ (2004) Mother-of-pearl shell (Pinctada maxima): stock evaluation for management and future harvesting in Western Australia, FRDC Project 1998/153, Fisheries Research Contract Report No. 10, Department of Fisheries, Western Australia

[38] Alansari AA, Shams AJ, Aldaggal AA (1994) Trial production of pearl oyster of Pinctada radiata trochophore larvae for use as larval food. Minister of Commerce and Agriculture Directorate of Fisheries National Mariculture Center, Bahrain

[39] Ehteshami F, Christianus A, Rameshi H, Harmin SA, Saad CR (2010) The effects of dietary supplements of polyunsaturated fatty acid on pearl oyster, Pinctada margaritifera L., gonad composition and reproductive output. Aquacult Res 42: 613-622

[40] Loosanoff VL, Davis HC (1963) Rearing of bivalve mollusks. Adv Mar Biol 1: 1-136

[41] Galtsoff PS (1964) The American oyster Crassostrea virginica Gmelin. Fish Bull 64: 1479

[42] Helm MM, Bourne N (2004) Hatchery culture of bivalves; a practical manual. In: Lovatelli, A. (Ed), FAO Fish. Tech. Paper No. 471, pp 177

[43] Mies M, Braga F, Scozzafave SS, Sumida PYG, Lemos D (2013) Successful spawning and a possible solution for broodstock mortality in giant clams (Tridacnidae): a neurotransmitter injection through the byssal orifice. Aquacult Res 44: 671-676 
Fig. 1. Location of the sampling site, Weno Island in Chuuk State, Federated State of Micronesia.

Fig. 2. Specificity test of the rabbit anti-BLP oyster egg protein serum by Western blotting assay. a. An assay with the serum before the immunoadsorption. $\mathbf{b}$. An assay with the immunoadsorbed rabbit anti-BLP oyster egg protein IgG. M, molecular marker; 1, BLP oyster egg extract; 2-4, negative controls including somatic tissue protein extracted from the mantle and gills (2), digestive gland protein (3), and BLP oyster sperm protein (4).

Fig. 3. Titration curves of the indirect ELISA for BLP oyster egg protein. a. A result using the rabbit anti-BLP oyster egg protein serum before immunoadsorption as a primary antibody. b. A result using the immunoadsorbed rabbit anti-BLP oyster egg protein lgG. Somatic tissue represents somatic proteins extracted from the mantle, foot and

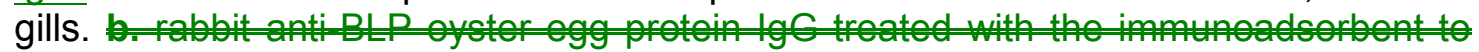

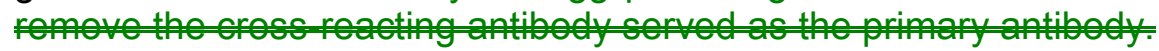

Fig. 4. Localization of Pinctada margaritifera egg protein revealed by immunohistochemistry. a. negative control. b. Staining with the anti-BLP oyster egg protein IgG.

Fig. 5. Specificity test of the rabbit anti-BLP oyster sperm protein serum by Western blotting assay. a. An assay with the serum before the immunoadsorption. b. An assay with the immunoadsorbed rabbit anti-BLP oyster sperm protein IgG. M, molecular marker; 1 , BLP oyster sperm protein; 2-6, negative controls including BLP oyster egg protein (2), digestive gland protein (3), mantle tissue protein (4), foot tissue protein (5), gill tissue protein (6).

Fig. 6. Titration curves of the indirect ELISA for BLP oyster sperm protein. a. A result using the rabbit anti-BLP oyster sperm protein serum before immunoadsorption as a primary antibody. b. A result using the immunoadsorbed rabbit anti-BLP oyster sperm IgG. Somatic tissue proteins extracted from the mantle (Man), foot, gill, digestive gland (Dig) and eggs. O.D., optical density.

Fig. 7. Gonad-Somatic Index (GSI) of female BLP oysters in different reproductive stages determined using indirect ELISA.

Fig. 8. Relationship between the size as shell length and the potential fecundity of ripe BLP oysters determined using indirect-ELISA.

Fig. 9. Gonad-Somatic Index (GSI) of male BLP oysters in different reproductive stages determined using indirect ELISA. 


\section{Table caption}

Table 1. Biometric information of Pinctada margaritifera collected from Weno Island, Chuuk State and Tahiti.

Table 2. The dry weights of single egg of marine bivalves determined through various studies and their biochemical composition.

Table 3. Reproductive effort of female pearl oysters measured using various methods. 


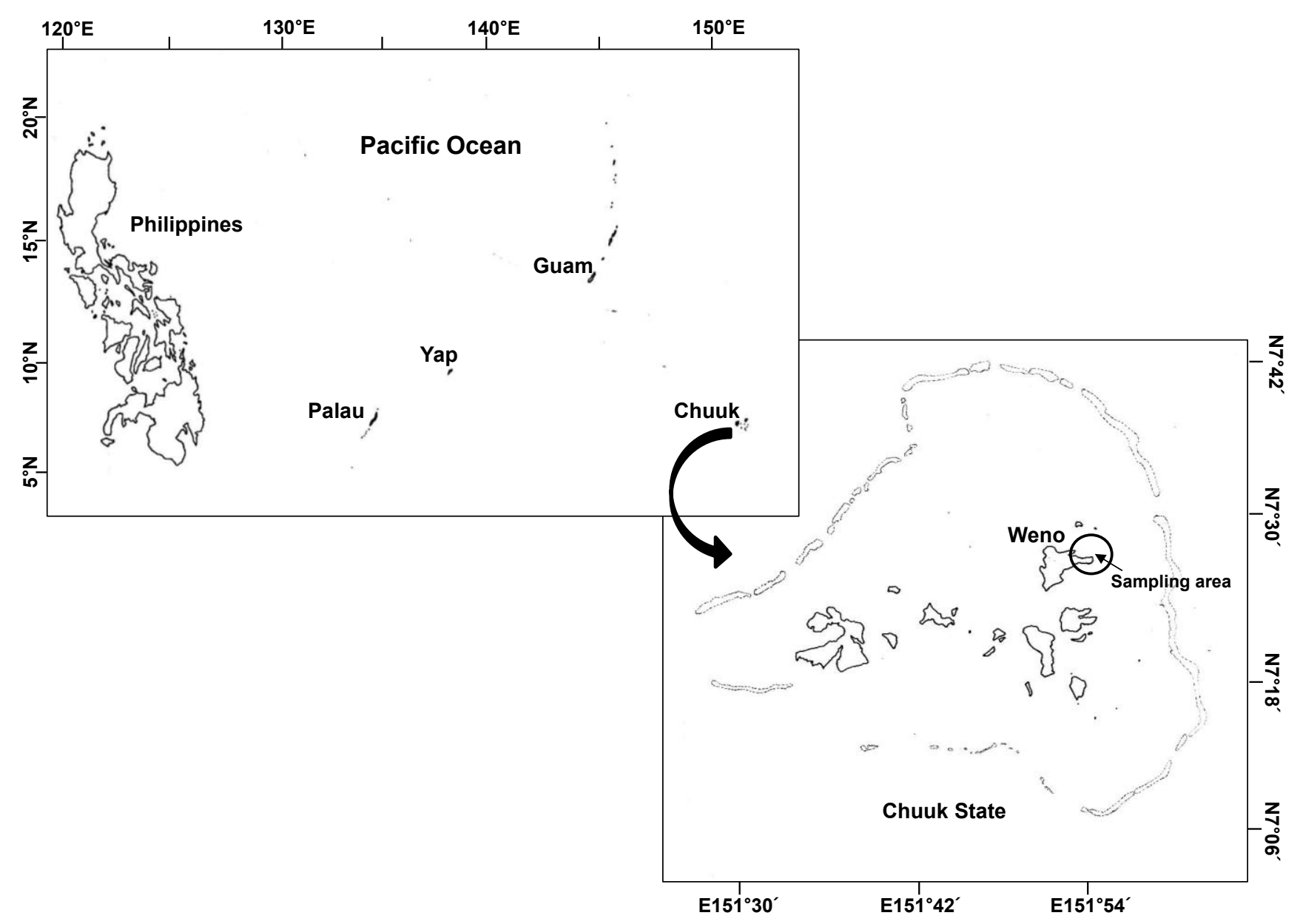

Fig. 1. 


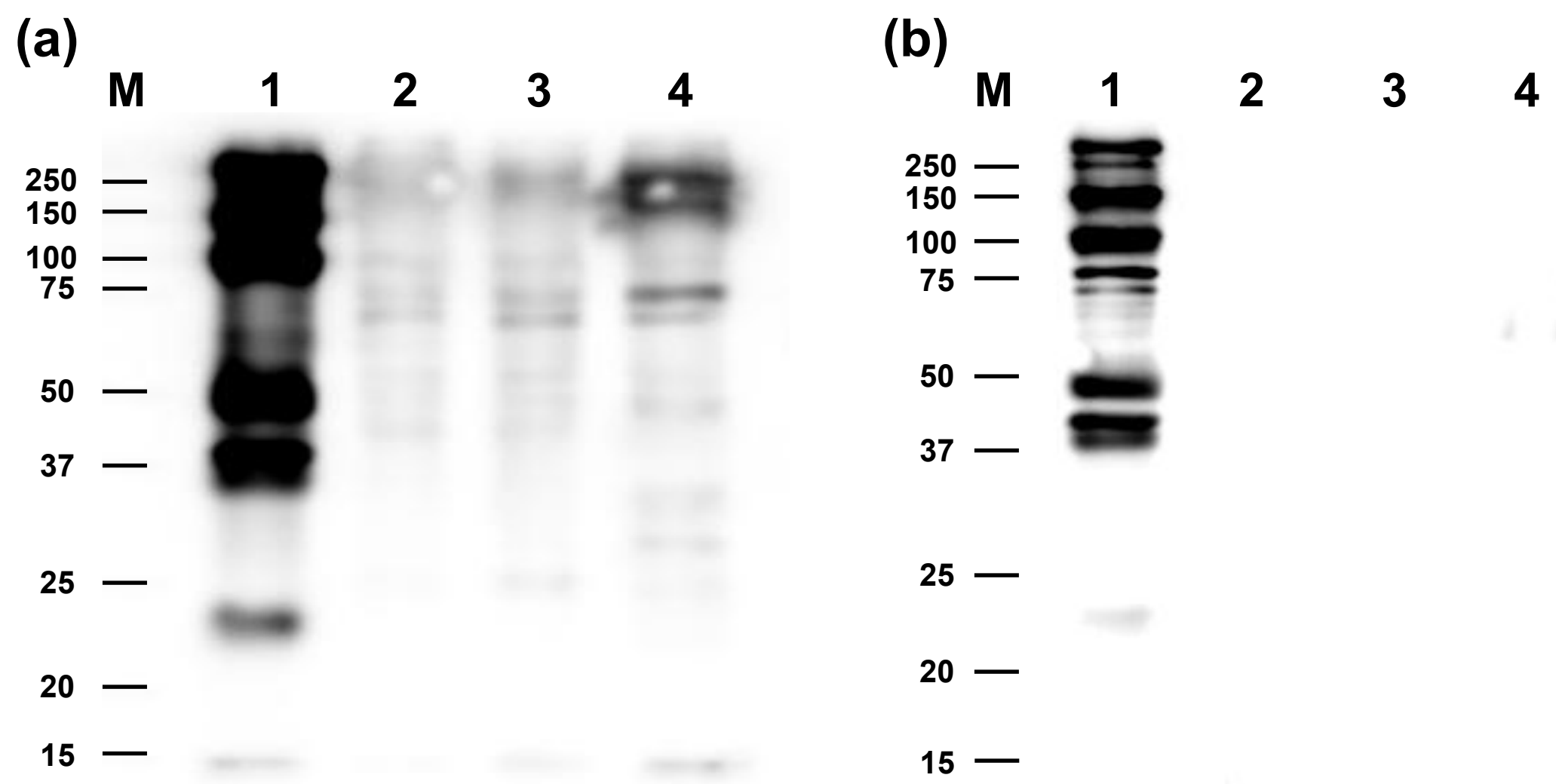

Fig. 2. 
(a)

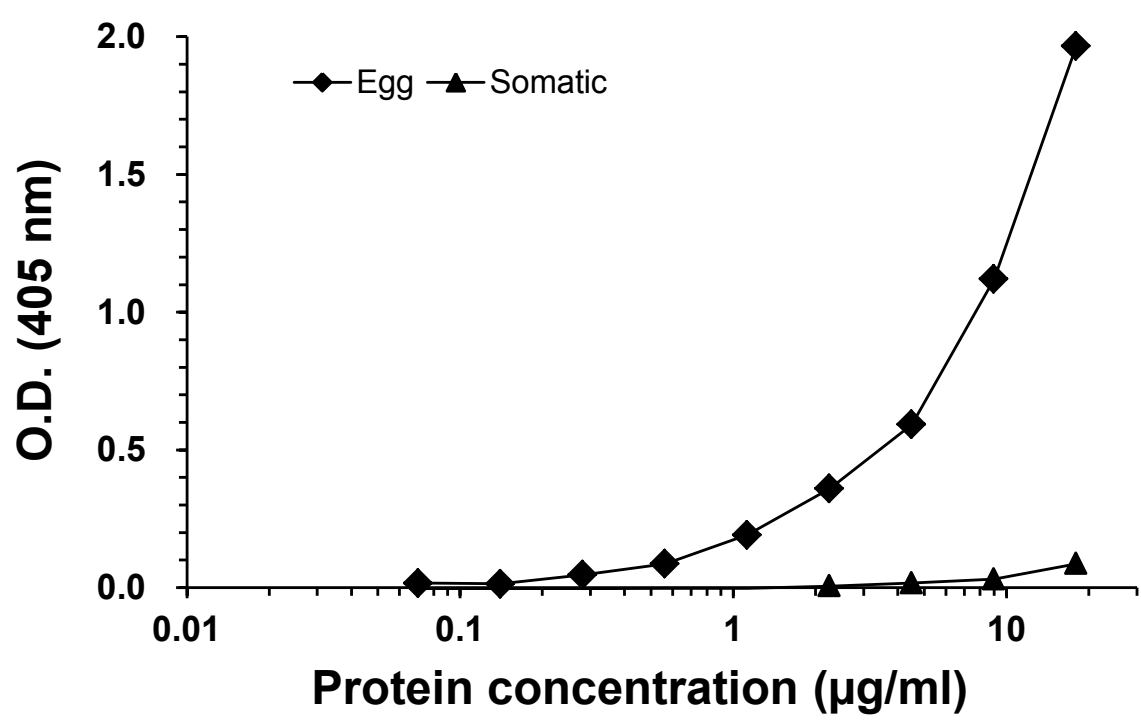

(b)

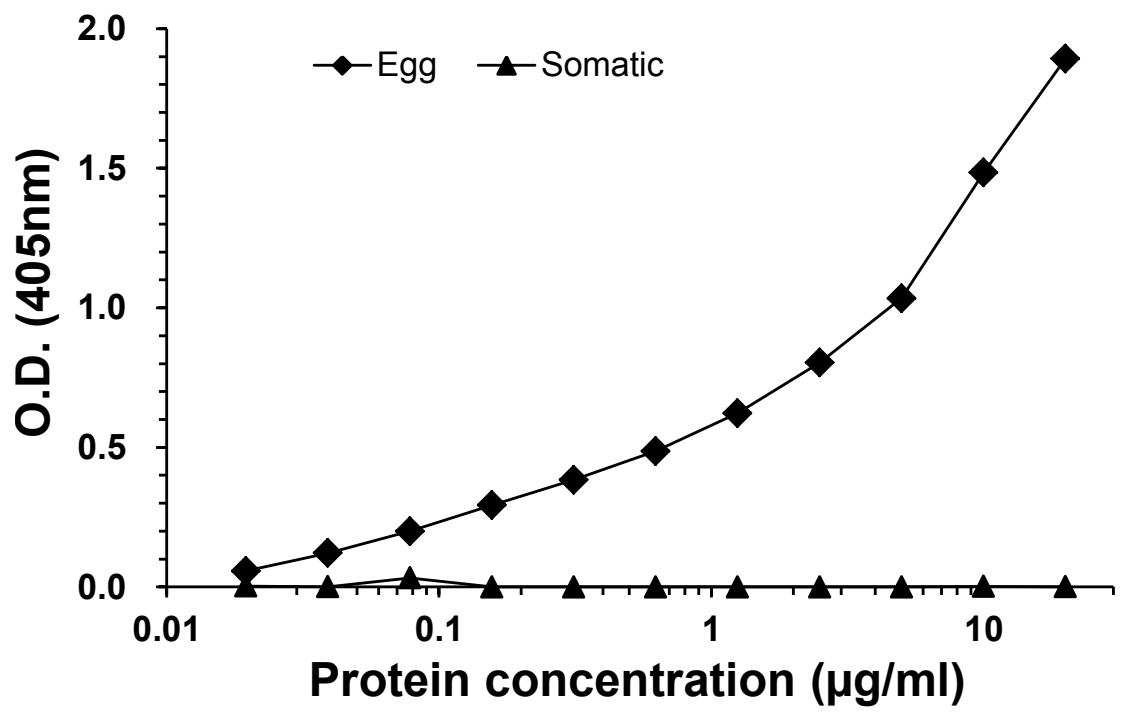

Fig. 3. 


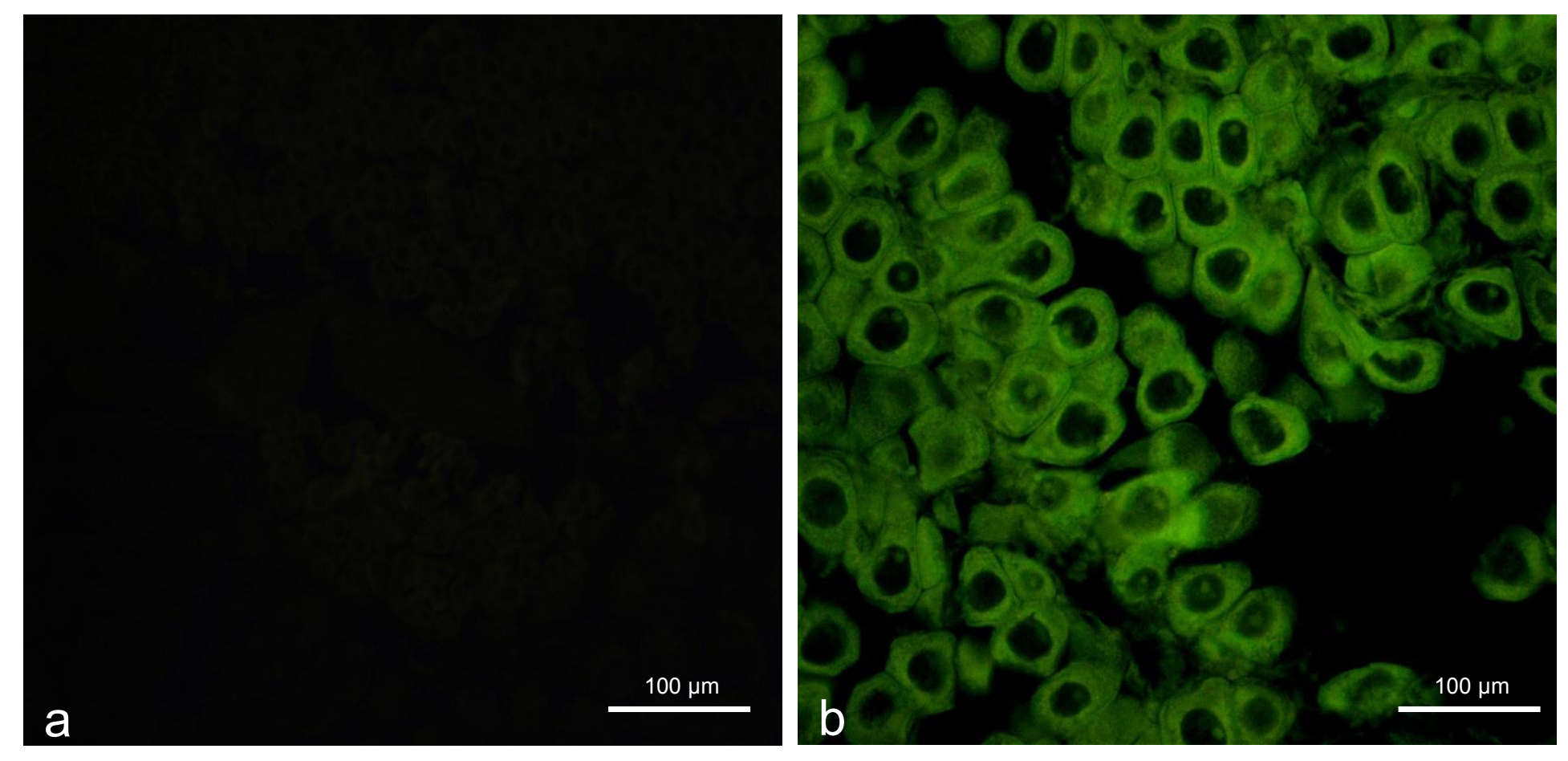

Fig. 4. 
(a)

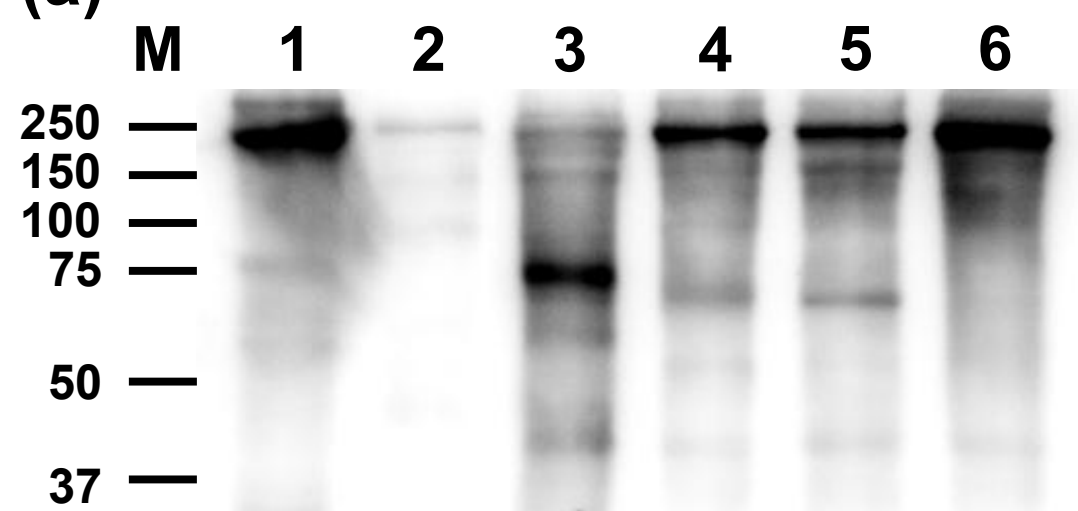

$25-$

$20-$

$15-$ (b) $\begin{array}{lllllll}M & 1 & 2 & 3 & 4 & 5 & 6\end{array}$

$$
\begin{aligned}
& 250= \\
& 150= \\
& 15= \\
& 50- \\
& 37- \\
& 25- \\
& 20- \\
& 15-
\end{aligned}
$$

Fig. 5. 
(a)

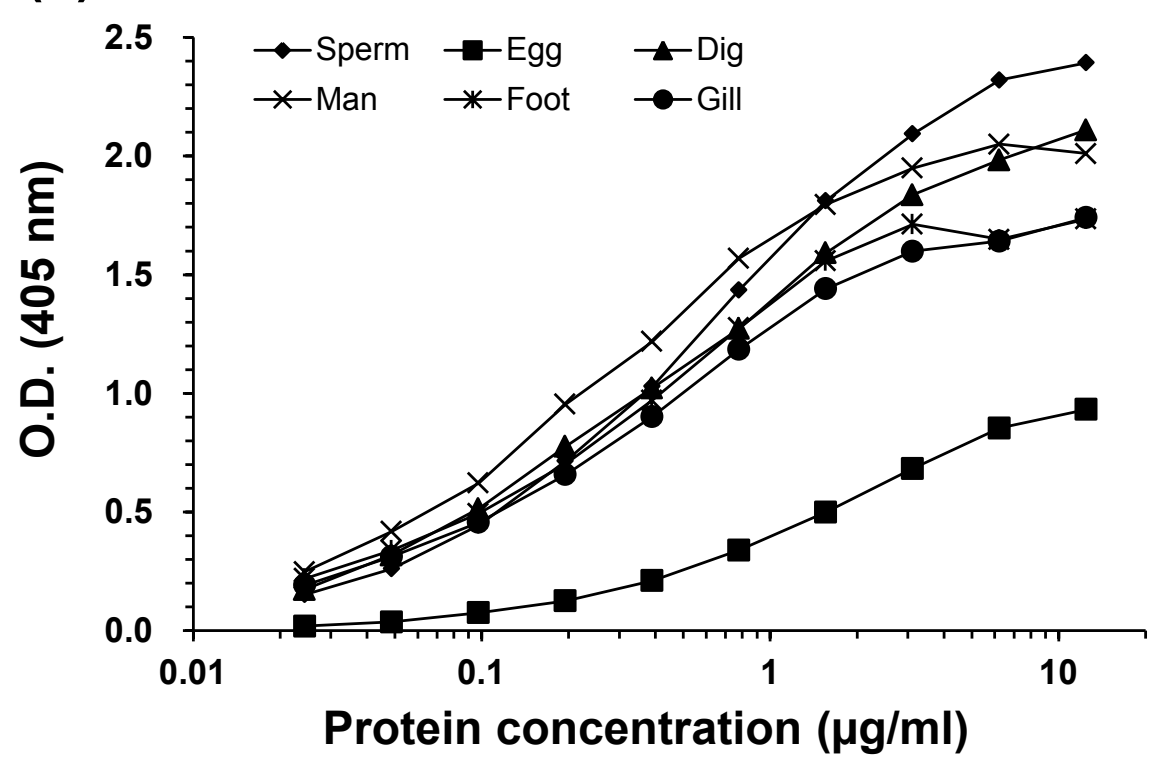

(b)

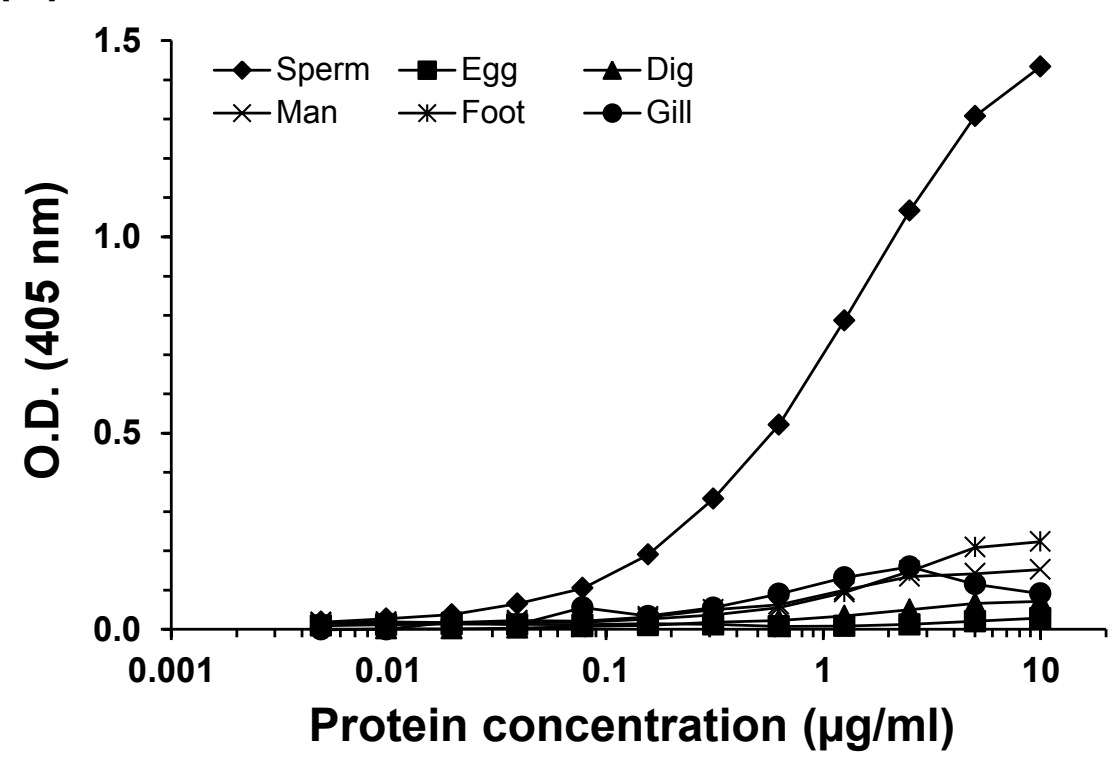

Fig. 6. 


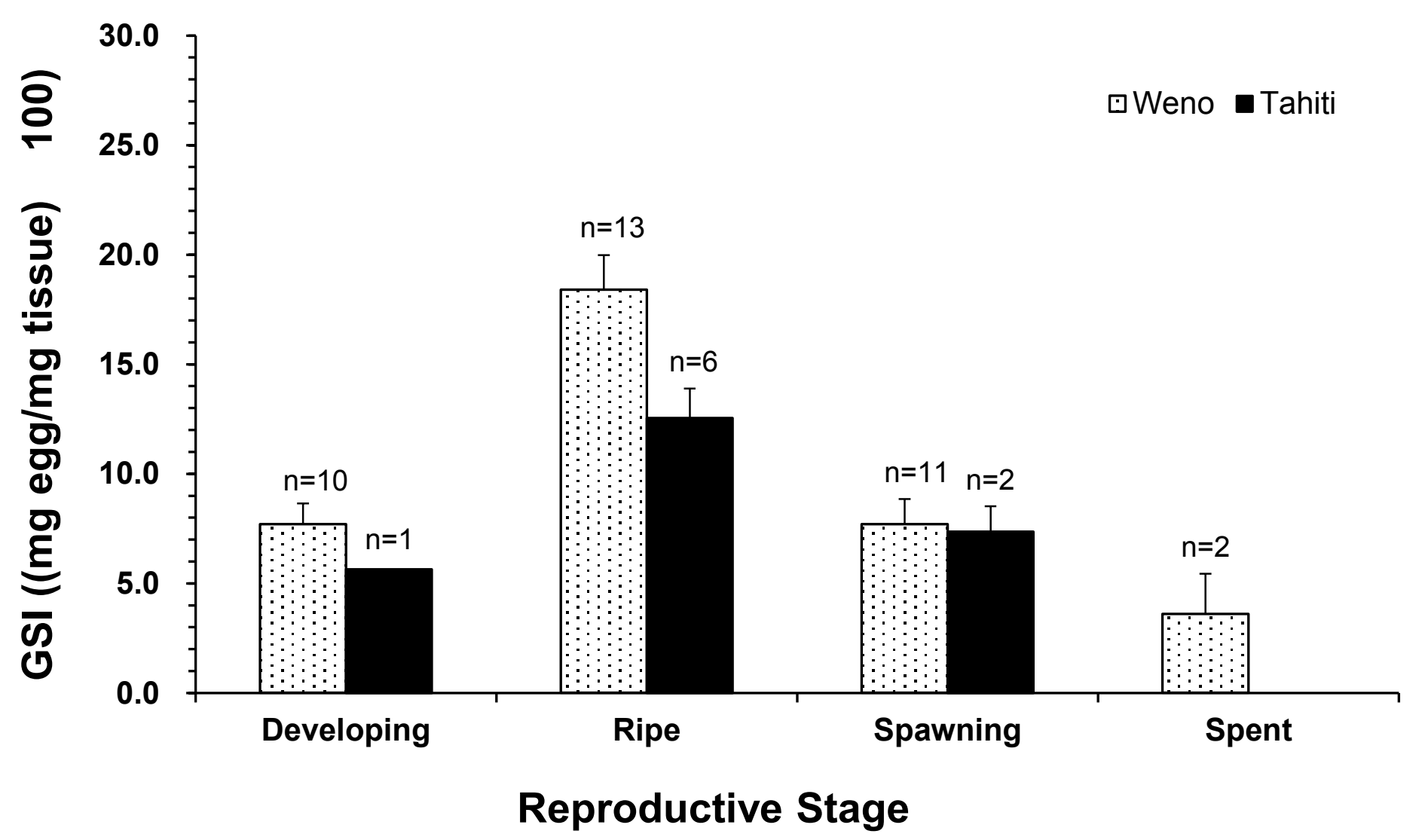

Fig. 7. 
$\bullet$ Weno $\square$ Tahiti

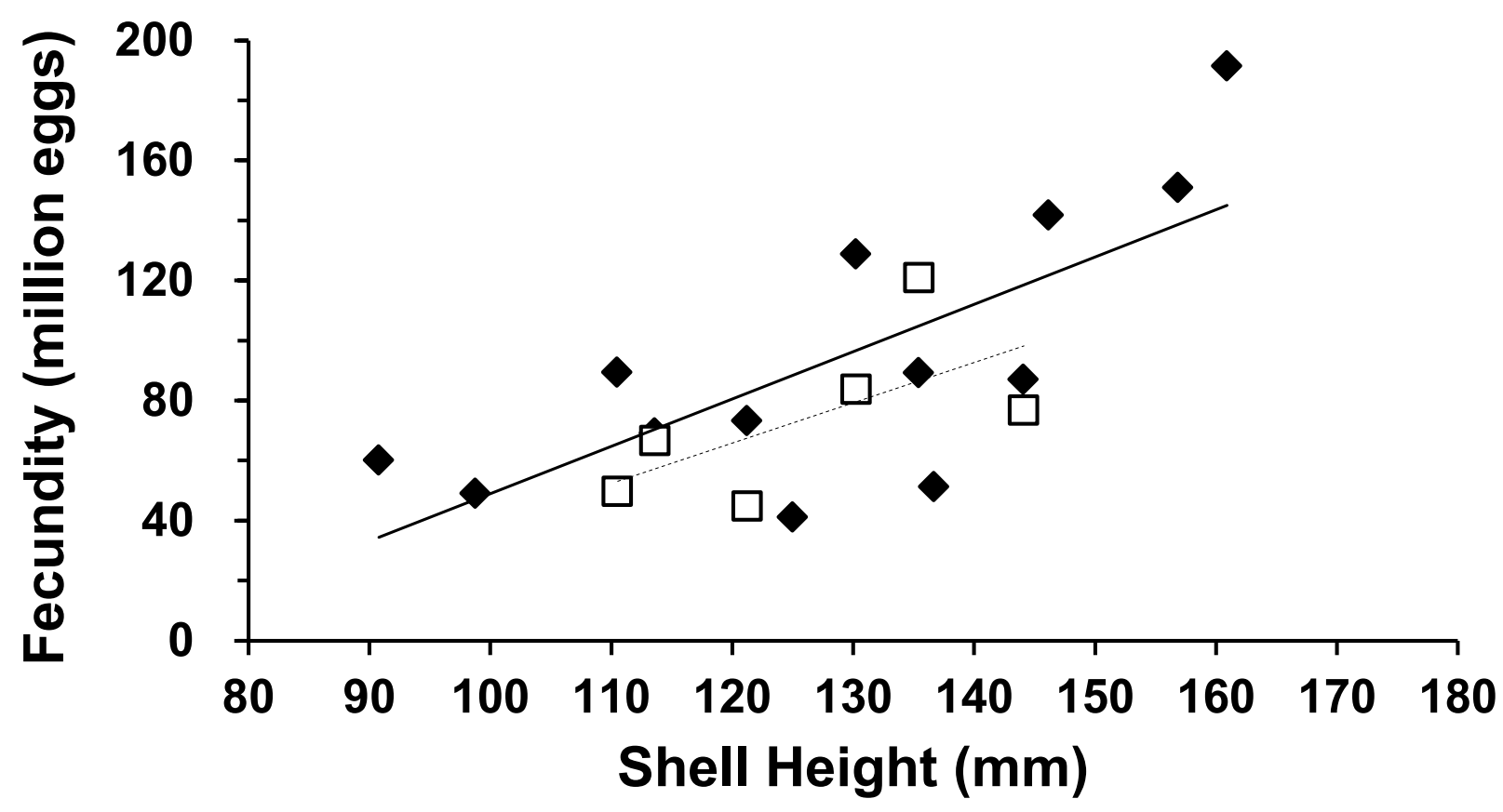

Fig. 8. 


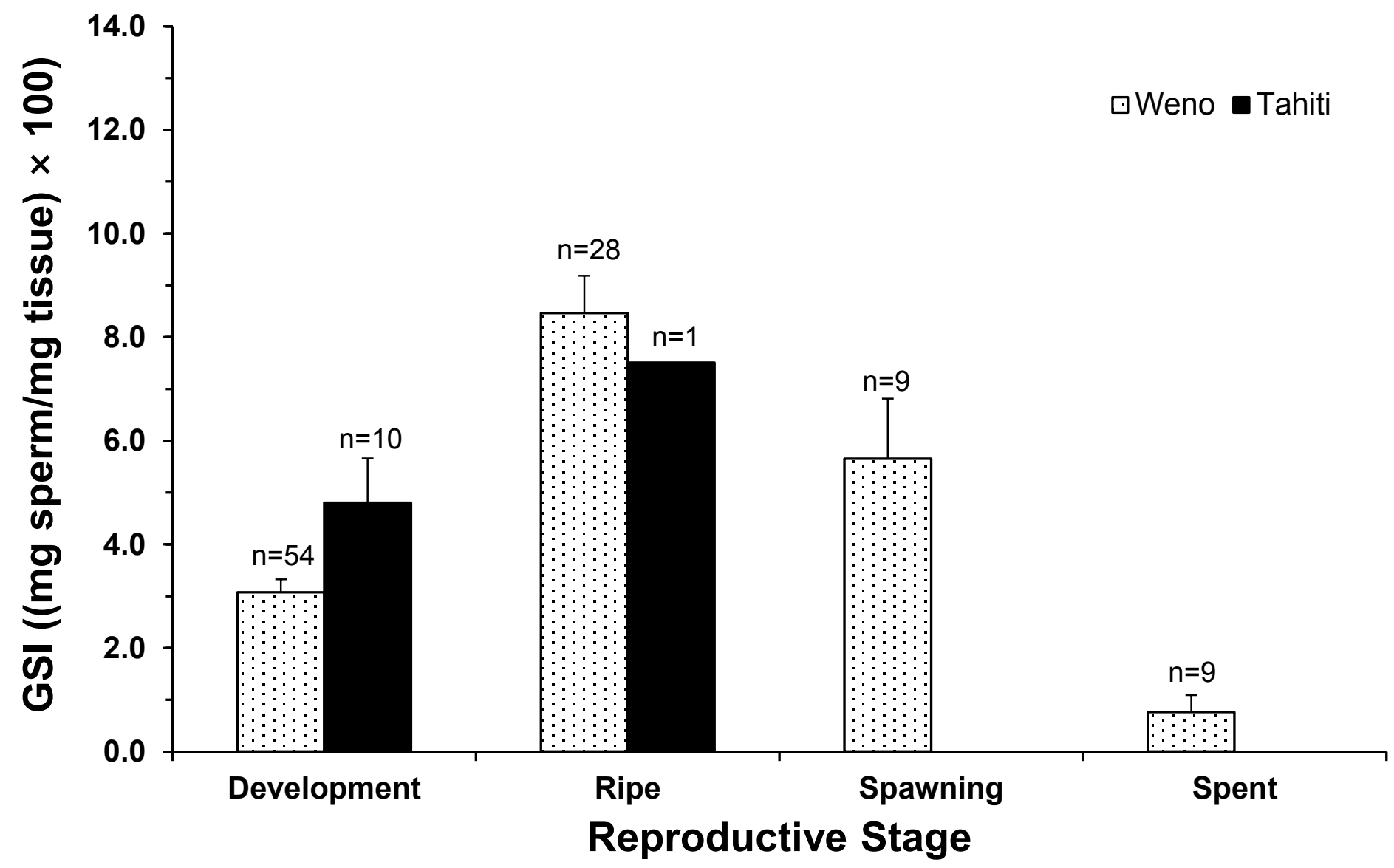

Fig. 9. 
Table 1. Biometric information of Pinctada margaritifera collected from Weno Island, Chuuk State and Tahiti.

\begin{tabular}{ccccc}
\hline & $\mathrm{N}^{1}$ & $\mathrm{SEX}$ & $\mathrm{SH}(\mathrm{mm})^{2}$ & ${\text { TDWT }(\mathrm{g})^{3}}^{\text {Weno Island }}$ \\
& 36 & $\mathrm{~F}^{4}$ & $90.78-171.98$ & $3.74-14.47$ \\
& 100 & $\mathrm{M}^{5}$ & $43.51-169.83$ & $0.34-13.25$ \\
& 9 & $\mathrm{~F}$ & $134.30-145.00$ & $4.81-10.83$ \\
Tahiti Island & 11 & $\mathrm{M}$ & $110.80-155.30$ & $3.08-8.11$ \\
\hline
\end{tabular}

\footnotetext{
${ }^{1} \mathrm{~N}$ : number of oysters

SH: shell height

${ }^{3}$ TDWT: tissue dry wight

${ }^{4} \mathrm{~F}$ : female

${ }^{5}$ M: male
} 
Table 2. The dry weights of single egg of marine bivalves determined through various studies and their biochemical composition.

\begin{tabular}{lccccl}
\hline Species & $\begin{array}{c}\text { Egg dry weight } \\
(\mathrm{ng})\end{array}$ & Protein (\%) & Carbohydrate (\%) & Lipid (\%) & Author \\
\hline Mercenaria mercenaria & 51 & 40.0 & 8.0 & 14.0 & Lee and Heffernan \\
Saxidomus purpuratus & 95 & 37.4 & 10.8 & 11.4 & Park et al. [22] \\
Ruditapes philippinarum & 22 & 41.0 & - & - & Park and Choi [6] \\
Crassostrea virginica & 12 & 50.0 & 9.0 & 21.0 & Lee and Heffernan \\
Crassostrea gigas & - & 74.0 & $7.0-12.0$ & $16.0-$ & Massapina et al. [33] \\
Crassostrea gigas & 13 & 41.0 & 11.7 & 25.5 & Kang et al. [13] \\
Pinctada margaritifera & 14.3 & 45.5 & 5.8 & 21.5 & Present study \\
\hline
\end{tabular}


Table 3. Reproductive effort of female pearl oysters measured using various methods.

\begin{tabular}{|c|c|c|c|c|c|c|}
\hline Species & Method & GSI $(\%)^{6}$ & Fecundity & Locality & Author & Remark \\
\hline Pteria sterna & Stereology & - & - & $\begin{array}{l}\text { Bahía de La } \\
\text { Paz, Mexico }\end{array}$ & $\begin{array}{l}\text { Cáceres-Puig et al. } \\
{[36]}\end{array}$ & $\begin{array}{l}\text { gonad volume } \\
\text { fraction } \\
\text { was measured }\end{array}$ \\
\hline Pinctada maxima & Weighing & - & $19.7-29.5 \times 10^{6}$ eggs & $\begin{array}{l}\text { Exmouth Gulf, } \\
\text { Australia }\end{array}$ & $\begin{array}{l}\text { Hart and Friedman } \\
\text { [37] }\end{array}$ & $\begin{array}{l}\text { The gonad occupied } \\
18-29 \% \text { of the } \\
\text { visceral mass. }\end{array}$ \\
\hline Pinctada radiata & $\begin{array}{l}\text { Direct } \\
\text { counting }\end{array}$ & - & $0.95-1.7 \times 10^{6}$ eggs & $\begin{array}{l}\text { Ras Hayan, } \\
\text { Bahrain }\end{array}$ & Alansari et al. [38] & $\begin{array}{l}\text { Inducing the } \\
\text { spawning by thermal } \\
\text { shock. }\end{array}$ \\
\hline $\begin{array}{l}\text { Pinctada } \\
\text { margaritifera }\end{array}$ & Weighing & $4-11 \%$ & - & $\begin{array}{l}\text { Takapoto Atoll, } \\
\text { French } \\
\text { Polynesia }\end{array}$ & Pouvreau et al. [3] & $\begin{array}{l}\text { Weighing dry tissue } \\
\text { before and after } \\
\text { spawning. }\end{array}$ \\
\hline $\begin{array}{l}\text { Pinctada } \\
\text { margaritifera }\end{array}$ & $\begin{array}{l}\text { Direct } \\
\text { counting }\end{array}$ & - & $2.5-20.0 \times 10^{6}$ eggs & $\begin{array}{l}\text { Lavan Island, } \\
\text { Persian Gulf }\end{array}$ & Ehteshami et al. [39] & $\begin{array}{l}\text { Spawning was } \\
\text { induced by thermal } \\
\text { shock }\end{array}$ \\
\hline $\begin{array}{l}\text { Pinctada } \\
\text { margaritifera }\end{array}$ & $\begin{array}{l}\text { Indirect- } \\
\text { ELISA }\end{array}$ & $\begin{array}{l}7.3- \\
26.4 \%\end{array}$ & $41.1-191.4 \times 10^{6}$ eggs & $\begin{array}{l}\text { Weno Island, } \\
\text { Micronesia }\end{array}$ & Present study & \\
\hline $\begin{array}{l}\text { Pinctada } \\
\text { margaritifera }\end{array}$ & $\begin{array}{l}\text { Indirect- } \\
\text { ELISA }\end{array}$ & $\begin{array}{l}9.6- \\
18.5 \%\end{array}$ & $44.7-120.9 \times 10^{6}$ eggs & $\begin{array}{l}\text { Tahiti, French } \\
\text { Polynesia }\end{array}$ & Present study & \\
\hline
\end{tabular}

\footnotetext{
${ }^{6}$ GSI: gonad somatic index, the proportion of egg weight to total tissue weight
} 